\title{
Efficiency of corporate finance: formation of accounting and management tools
}

\author{
Guzaliya Klychova $^{1}$, Alsou Zakirova ${ }^{1, *}$, Almaz Nigmetzyanov $^{2}$, Igor Nikitenko ${ }^{2}$, and \\ Gamlet Ostaev ${ }^{3}$ \\ ${ }^{1}$ Kazan State Agrarian University, 65, Karl Marx str., 420015, Kazan, Russia \\ ${ }^{2}$ Kazan (Volga) Federal University, 18, Kremlevskaya str., 420008, Kazan, Russia \\ ${ }^{3}$ Izhevsk State Agricultural Academy, 11, Studencheskaya str., 426069, Izhevsk, Russia
}

\begin{abstract}
The commercial sector of the economy is the guarantor of the stability of the state functioning, since the economic subjects employed in it are able to combine personal (entrepreneurial) interests with the interests of the population, thanks to their economic potential formed at the expense of business processes aimed at profit (the main source of financing measures to meet human needs for the existing benefits). The purpose of the study - the formation of accounting and management tools that allow corporations to conduct a comprehensive analysis of the effectiveness of financial relationships, taking into account all the conditions of activity inherent in big business. In the course of the study the calculativeconstructive, deductive and inductive methods were used, which allow to interconnect dialectically resultant and factor efficiency indicators, in our case, in the sphere of corporate finance, through multiple-additive correlation of efficiency and cost of financial relations in big business. The article presents the system of indicators developed by the authors, offered to corporations for assessment by the accounting and management apparatus of efficiency of their financial relations, which play the key role in business due to the greatest liquidity of monetary resources. The toolkit of such a system is built on the study of controlled and uncontrolled conditions of corporations' functioning. The use by corporations of the recommended author's approach will provide them with the optimization of the result and costs (profit and expenses) and, accordingly, the effectiveness and cost effectiveness (direct and indirect profitability or profitability) of activities, by which their financial efficiency is determined.
\end{abstract}

\section{Introduction}

A special role in obtaining mutual benefits in maintaining the balance between entrepreneurial and public interests belongs to big business, which is dominated by corporations that have huge competitive advantages in market segments due to the hypertrophic concentration of monetary resources [1-3]. At the same time, managers of corporations, first of all, the top management of their activities, need to be aware of the fact

\footnotetext{
*Corresponding author: zakirovaar@mail.ru
} 
that business leadership is determined not only by the present, but also by future realities affecting the result and costs, and together with them on the effectiveness and cost of business actions, so the solution of this issue is a priority $[4,5]$. Creation of the system of indicators, which most objectively reflect the level of efficiency of corporate finance, is an important tool for accounting and management personnel.

Modern trends in corporate finance management are associated with the globalization of the financial sphere and, as a consequence, the emergence of additional risks due to the increasing interdependence between the various structural elements of the financial market [6-9]. Therefore, there is a need to apply innovative methods of corporate finance management in order to promptly respond to changes in the external environment, while maintaining the focus of the company's development strategy [10-13].

The set of methods for managing the corporation's finances depends on a number of factors, namely:

- availability of certain strategic goals $[14,15]$;

- ownership structure, specifics and scale of activity [16];

- level of financial management [17];

- the principles of making decisions about strategic development $[18,19]$;

- the forms and sources of funding [20-23];

- minimization of organizational and managerial costs [24];

- organizational structure development [25].

The effectiveness of corporate financial management is influenced by the financial policy of the corporation. The financial policy of a corporation is understood as a set of purposeful actions to achieve strategic and tactical goals for extracting the maximum positive effect from financial and economic activities [26]. The main constituent elements of financial policy are financial strategy and tactics, financial management system, financial mechanism [27-29].

When carrying out financial policy, the management of the corporation uses all available financial forms, methods, techniques and tools to influence economic processes $[30,31]$. The basic principles of using own and borrowed funds to improve profitability, increase fixed and current assets, and increase sales are developed [32].

The effectiveness of financial policy is influenced by internal and external conditions of financial and economic activity of the company (Fig. 1).

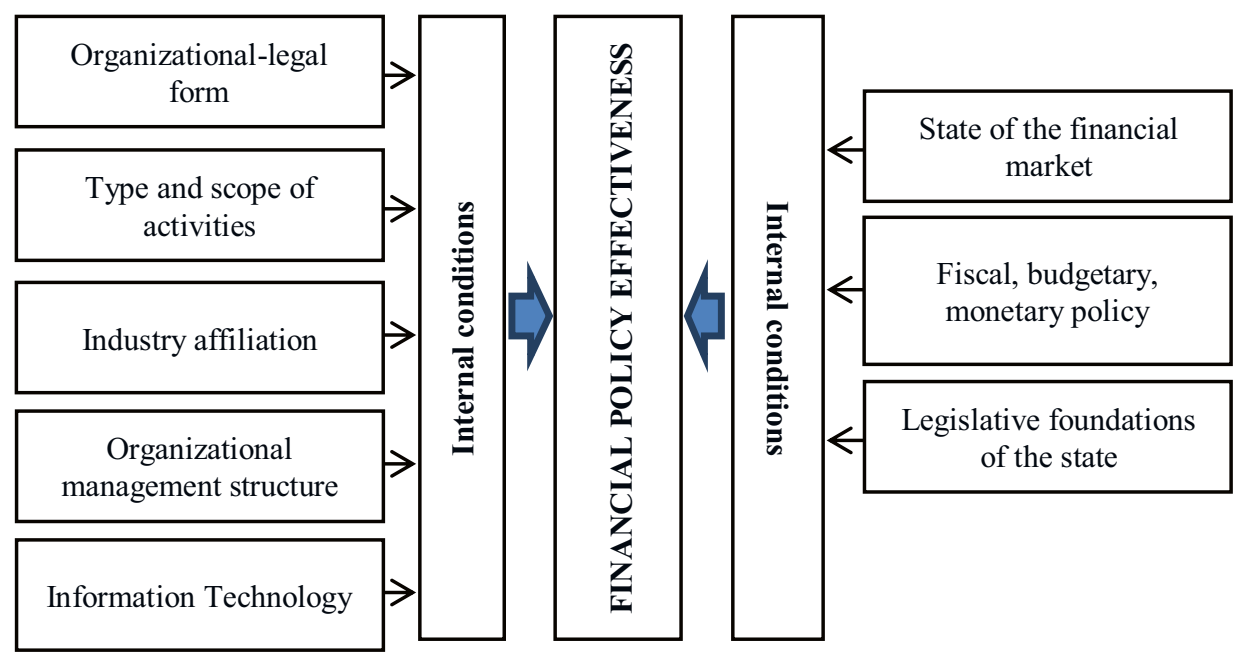

Fig. 1. Objects of internal control of stocks. 
The subject of corporate finance management is the financial service of the enterprise. Financial service influences on objects of management by means of financial methods and tools. Financial methods of corporate finance management include: financial resources, sources of financial resources, financial relations.

The structure of management of the corporation includes the following stages of management:

Stage 1. At this stage, the activity of executors, who directly carry out financial activity, is organized. As performers at the first stage, the financial and economic service and officials, who are engaged in planning and expenditures of resources, are distinguished.

Stage 2. At this stage the management manages the corporation with the help of a special functional body - the financial department. The finance department performs the following functions:

- accumulates and analyzes information;

- provides information and consulting services;

- prepares reports on the activities of the corporation;

- prepares investment projects;

- summarizes accounting information;

- prepares accounting and tax documents;

- generates consolidated statements of subdivisions.

- distributes profits from joint activities of member enterprises of the corporation;

- distributes credit resources;

- establishes external economic relations;

- draws up foreign trade contracts.

Activities of the financial department are coordinated with the activities of the production and supply and sales departments.

The third level is represented by the supreme body of the corporation (general meeting of shareholders and supervisory board), executive body (general director and management board).

In order to effectively perform the set financial tasks, it is necessary to coordinate the interaction of executors, departments and services that are part of the organizational structure of financial management

In modern conditions, the issues of assessing the effectiveness of the corporate finance management system do not lose their relevance [33]. When assessing the effectiveness of financial management, the effect achieved in the corporation's finances and the financial resources that are spent during its achievement are taken into account. The main principles of assessing the effectiveness of corporate finance management include: financial transparency; stable and long-term sustainability of budgets; comprehensiveness of management decisions; integration with the overall management system; dynamic management, taking into account changes in internal and external environment factors, result-oriented budgeting; effective financial control, reporting and monitoring.

\section{Materials and Methods}

Corporate governance is commonly understood as a complex system of goals, objectives, principles, methodological tools that ensure effective interaction between the object and subject of corporate governance, in the strategic development of the enterprise.

Features of corporate governance are as follows:

1. Strategic orientation of corporate management;

2. Successful functioning of the enterprise in the external environment;

3. Creation of positive image of the enterprise;

4. Ensuring corporate social responsibility before stakeholders; 
The conceptual model of corporate governance can be represented as the following scheme (Fig. 2)

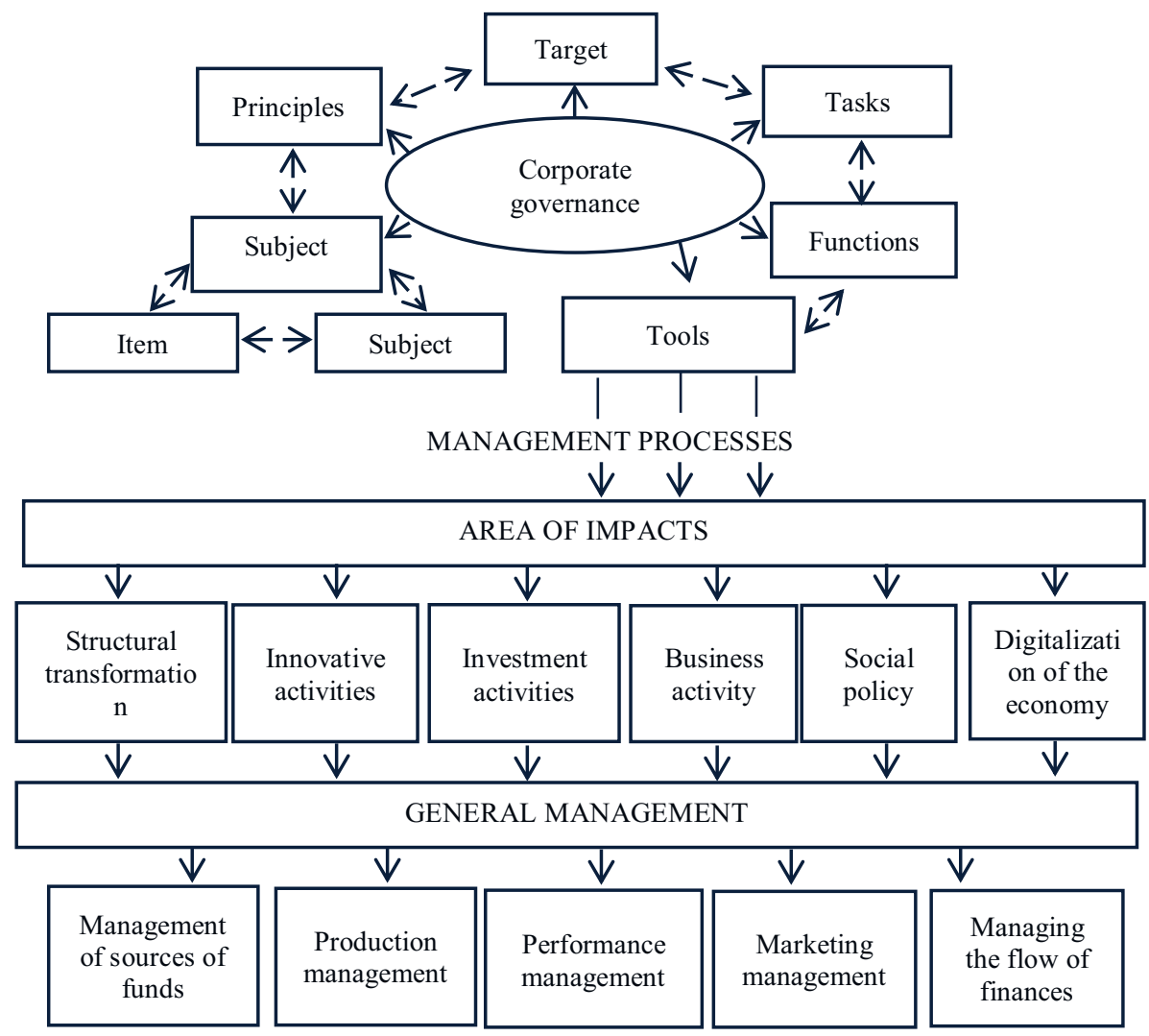

Fig. 2. Conceptual model of corporate governance.

The fundamental element of this model is the goal of corporate governance, which is to balance the interests of all participants of corporate interests. In achieving this goal:

- efficiency and effectiveness of financial and economic activity of the enterprise are increased;

- the level of social responsibility increases;

- the business reputation of the enterprise strengthens;

- the investment attractiveness of the enterprise increases;

- shareholders have the opportunity to control the activities of the enterprise, to participate in the management of the business.

To achieve the goal of corporate governance it is necessary to solve the following tasks:

- to develop and decide on the optimal organizational structure of the enterprise;

- to provide effective observance of the bases of functioning of governing bodies;

- to provide protection of interests of owners, shareholders;

- to provide a balanced interaction between the interested parties that affect the activities of the corporation;

- to strengthen the production and economic potential of the enterprise, and to attract investment;

- to provide maximum transparency of information about the corporation's activities, improving the information policy; 
- improve the system of managing finances, assets, and personnel;

- effectively manage current operations and increase profits;

- ensure the continuous functioning of the corporation;

- to pursue an effective social policy and increase the corporate social responsibility of the business.

The main functions of corporate governance are:

- the planning function. A corporate development program is developed, goals are set and tasks are defined (short-term and long-term) that must be solved to implement this program. Material, labor, financial and organizational resources necessary to achieve the planned results are determined;

- organization function. Managed and control systems are formed, the organizational structure of the corporation is developed, management bodies are formed, their competences are defined, and the interaction between structural subdivisions and managerial personnel is coordinated;

- management function. The subject of management influences the activity of the object of management so that the goals, which are formulated in the corporation's development program, are achieved;

- the control function. It implies continuous monitoring of the functioning and condition of the financial and economic activities of the corporation, the efficient expenditure of its resources:

- coordination function. It coordinates the activities of all objects and subjects of the corporate management system at various stages of the corporation's financial and economic activities. The coordination of activities is carried out taking into account the temporal, functional, and organizational aspects of operation.

The following principles form the basis of corporate governance:

1) The principle of centralization. This principle implies the concentration in a single management body of the mechanism for solving strategic issues of corporate functioning. According to this principle the decisions are made by those persons who have extensive knowledge and experience. In this connection duplication at performance of working operations and decision-making is eliminated. Accordingly, the overall management costs are reduced.

2) The principle of decentralization. Decisions related to the functioning of the corporation as a whole or individual divisions are made by officials of lower management bodies. The need for decentralization is caused by an increase in the volume of production and the complexity of production technology. In this case, there is a need for rapid adoption of management decisions by the heads of lower and middle levels of management. The degree of decentralization is influenced by the qualification and experience of the heads of subdivisions and their ability to make informed managerial decisions.

3) The principle of coordination. The activities of the structural subdivisions of the corporation are coordinated by the subdivisions themselves, depending on the conditions of the external and internal environment. Structural subdivisions can jointly develop the necessary activities, coordination of which can be assigned to one of the heads of these subdivisions.

4) The principle of using human capital. Most decisions are made by managers or employees of those units that are responsible for the implementation of these decisions. Powers, actions and responsibility of executors should be clearly defined within those units, which are responsible for the implementation of individual tasks. The higher management bodies should solve the issues, to which the lower structures do not have the authority;

5) The principle of effective use of business satellites, which promote interaction of the corporation with external counteragents. 
The subject of corporate governance is the system of relationships between subjects of corporate governance (management bodies) and the object of corporate governance (founders, shareholders, subsidiaries, business units, financial responsibility centers, production and other divisions of the corporation).

The tasks of corporate governance are solved with the help of methods, or management tools. Corporate governance methods are designed to solve various management tasks in order to ensure the effective development of corporations, as well as to influence the object of management in order to subsequently achieve the goals set.

Management methods are characterized depending on their focus, content and organizational form (Fig. 3).

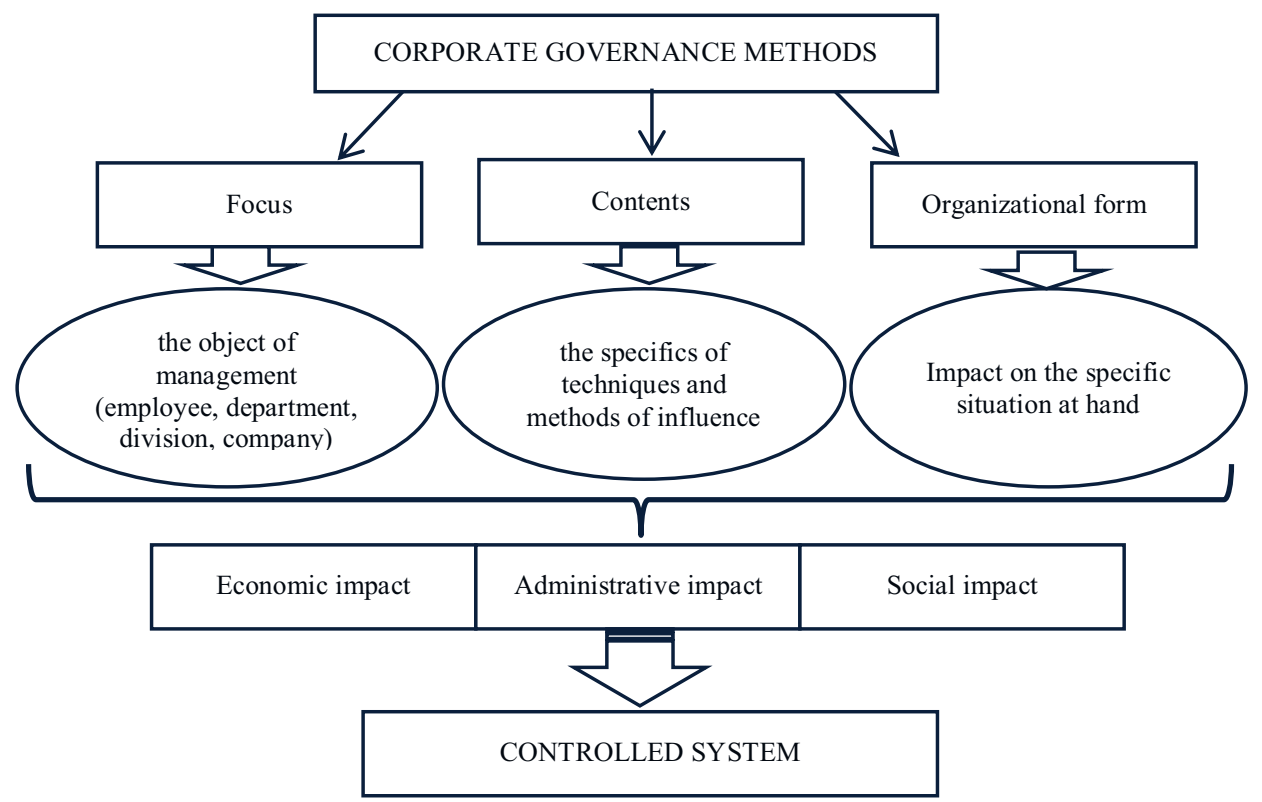

Fig. 3. Classification of methods of corporate management.

At classification of methods of corporate management on a direction, the maintenance and the organizational form their influence on managed system by means of administrative, economic and social levers is reflected.

In economic literature there are various classifications of methods of corporate management. At the same time, almost all methods combine the principles of content, orientation and organizational form. Therefore, in a generalized classification we can distinguish organizational-administrative, economic, social and psychological methods of corporate governance.

Organizational-administrative methods include methods of direct action, characterized by direct impact and based on responsibility and discipline. Organizational and administrative methods are represented by organizational design, regulation, rationing.

Economic methods of management include techniques and methods that affect executors by comparing costs and results of activities. Economic methods are represented by the system of wages and bonuses, financing, pricing, etc.

Socio-psychological methods of management include specific ways by which the impact on the personal relationships between members of the workforce and the social processes occurring in it is carried out. Socio-psychological methods are represented by motivation of executives, social planning, regulation of interpersonal and intergroup relations, creation and maintenance of moral climate in the collective. 
The processes of corporate management are influenced by macroeconomic and microeconomic factors.

Macroeconomic factors include globalization, socio-economic reforms, intensification of scientific and technological process, digitalization of economy, functioning of economy under pandemic conditions.

Microeconomic factors include the level of development of management (standards of corporate governance); accounting standards, quality of design of the annual report of the company; production and marketing policy of enterprises; development prospects of the largest enterprises (return on assets and capital, the ratio of share price to earnings per share).

Corporate governance processes affect areas such as structural transformation, innovation, investment, business, social policy, and the use of digital technologies.

The main goal of corporations is to increase competitiveness, increase profits and maximize returns on shareholders' capital. To achieve this goal it is necessary to carry out effective management of sources of funds, production, results of financial and economic activity, marketing management, management of corporate finances.

Profit can be increased due to the following factors: reducing the cost and price of production, increasing the efficiency of material and labor resources use (Fig. 4). 


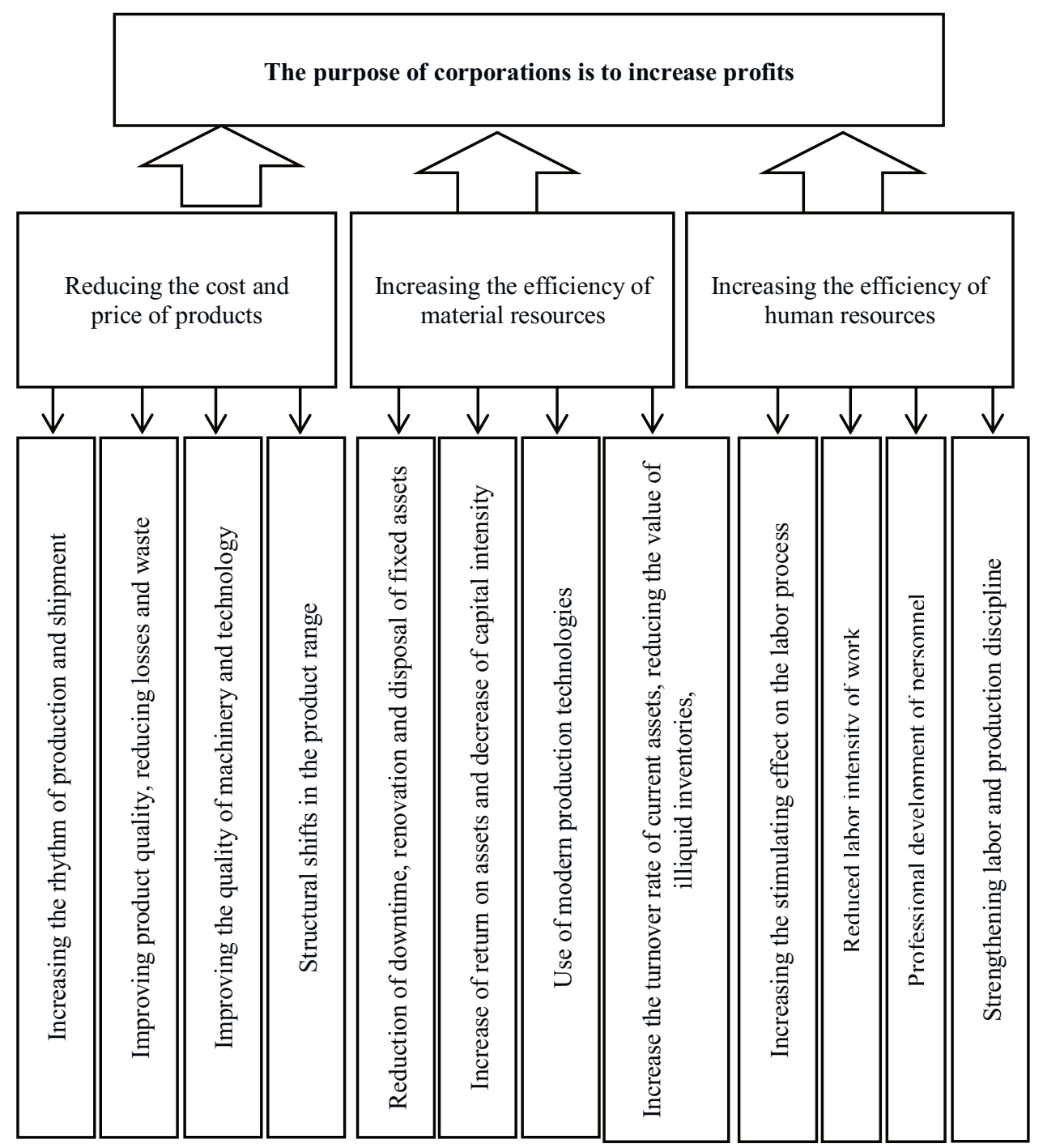

Fig. 4. Factors of increase in corporate profits.

In the economic literature give various definitions of the concept "corporate finance". So under corporate finance understand the economic relations that arise during the formation, distribution and use of funds generated in the process of production and sales of products. The main functions of corporate finance include distributional and accounting and control functions. Distributive function is in the rational distribution of funds in the production of products, works and services. The accounting and control function consists in the implementation of accounting and control measures in the formation, distribution and use of funds in the production and sale of products, works and services.

\section{Results}

The success of corporations depends on the accounting and management personnel and on the decisions made, accordingly research tools should be clear and qualitatively-adaptive. The activity of corporations is diversified and multidirectional and therefore depends on a 
variety of controlled and uncontrolled economic conditions, the list of which is much more differentiated in contrast to the economic conditions of medium and small businesses (Fig. 5).

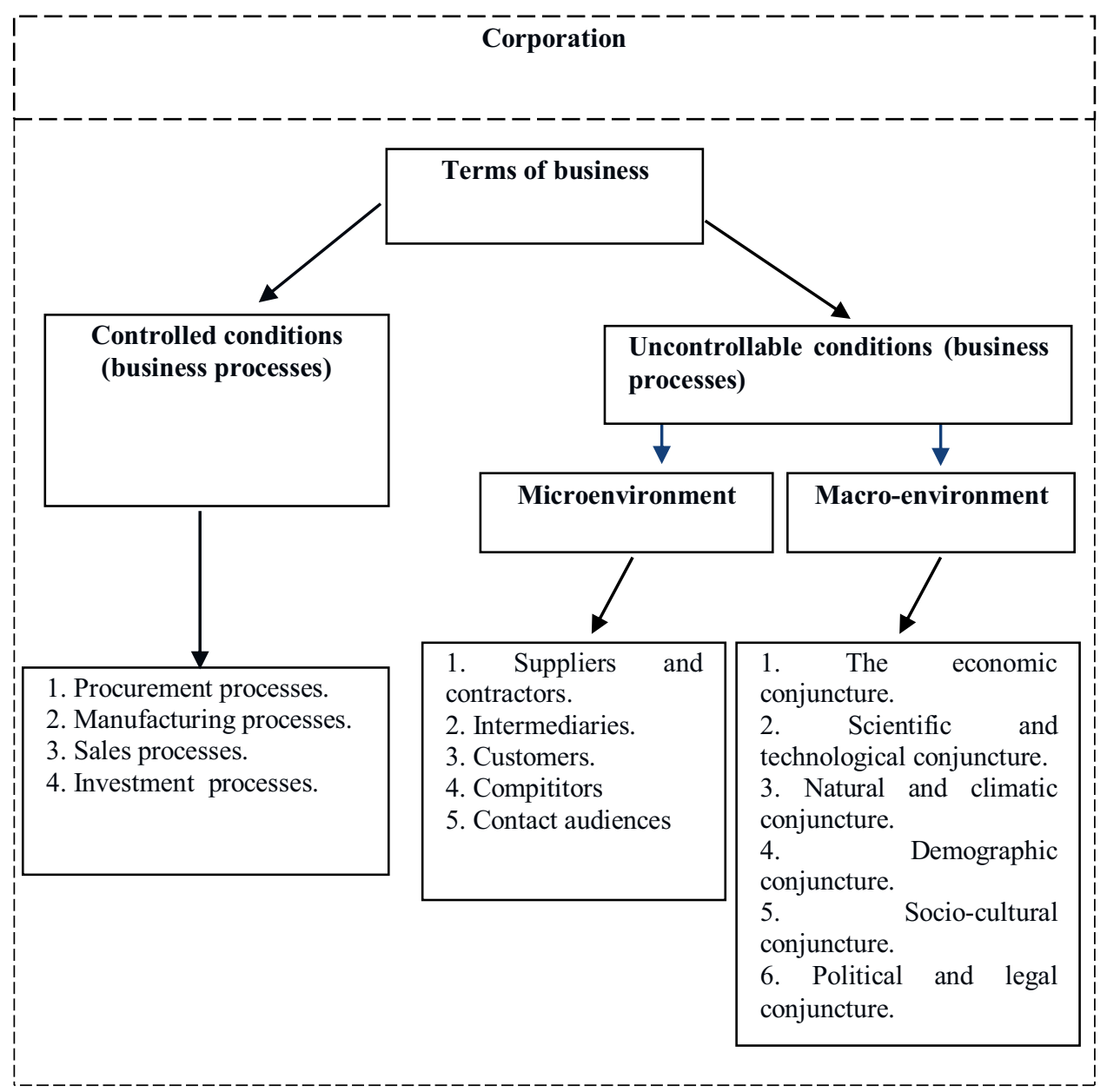

Fig. 5. The business environment for corporations.

It can be seen from the content of Figure 5 that from the elements of controlled conditions corporations, along with basic activities consisting of purchasing, production and sales processes, have other activities that include not only investment, but also innovation processes because of their acute need for both resources and technologies. The same concerns uncontrollable conditions, where for corporations in micro environment together with suppliers and contractors by degree of importance intermediaries, clients, competitors, contact audiences are equal, and in macro environment together with economic conjuncture all other types of conjuncture (scientific and technical, natural and climatic, demographic, social and cultural, political and legal) are of parity importance.

Management tools of corporate business finance can be - modeling, simulation forecasting and other economic-financial methods. Any task set should be supported by timely analysis of predicted actions. The predictive model should take into account a given course in the form of economic effect, for these purposes we propose to apply such economic tool as step-by-step integrated approach. The proposed methodology of the integrated approach will solve any tasks, regardless of what the financial state of the 
business, as this approach takes into account both positive trends and negative trends (from the state of losses to the state of financial well-being).

The proposed management model takes into account both resource potential and alternative ways of business development (Figure 6).

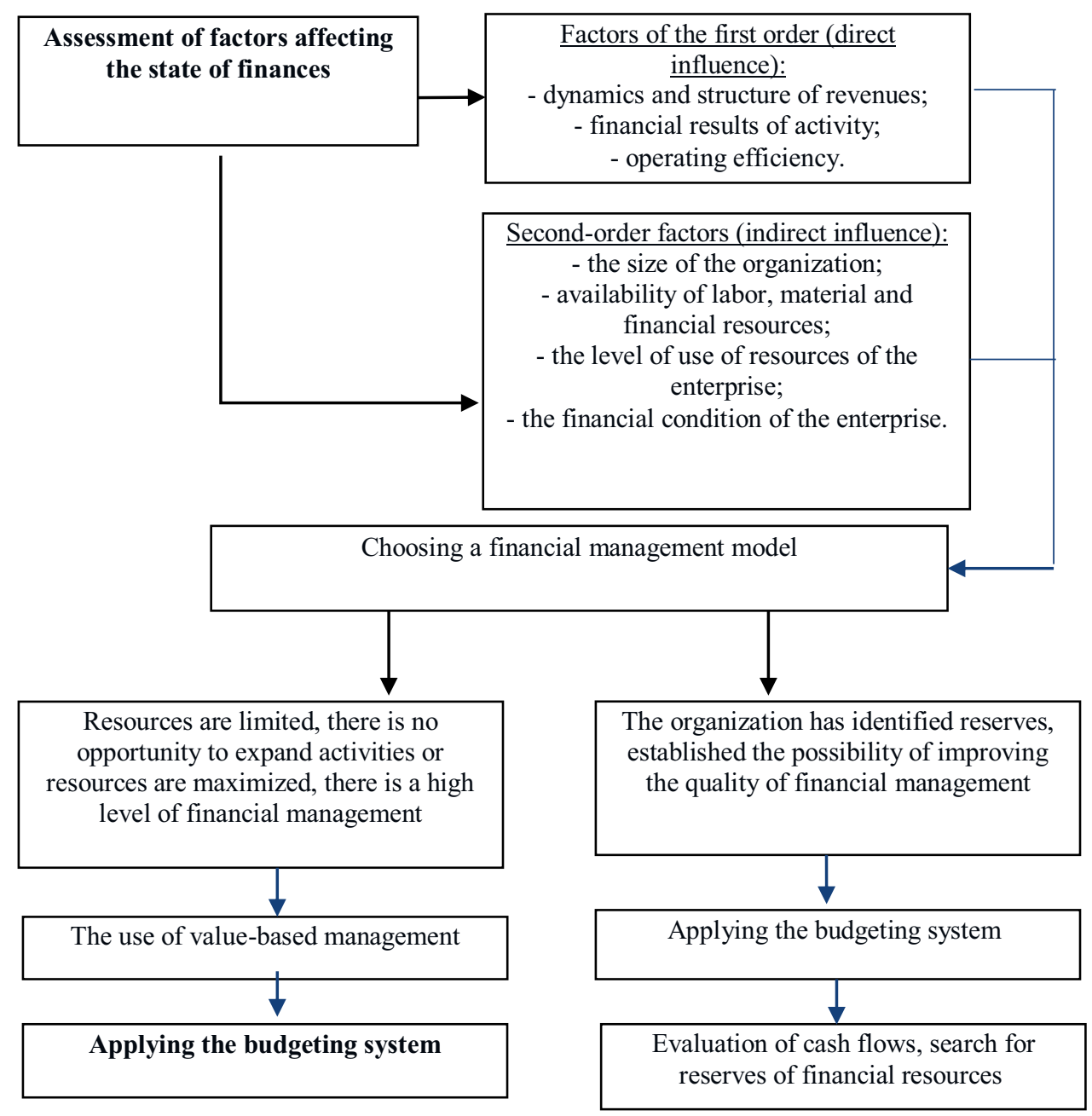

Fig. 6. Recommended algorithm of corporate finance management model choice (author's elaboration).

Economic effect of the given model of management is directly focused on business processes and their realization with the subsequent reception of planned result.

Taking into consideration the considered elements let's form direct (direct) and indirect (indirect) indicators of corporate finance effectiveness reflecting in general and in particular profitability of these economic subjects (formulas (1), (2), (3), (4), (5), (6), (7), (8)):

$$
E F_{c f(p)}=\frac{\left(I_{b}-E_{b}\right)+\left(I_{s}-E_{s}\right)}{E_{b p}+E_{m i}+E_{m a}},
$$

where $E F_{c f(p)}$ is the aggregate direct efficiency of corporate finance;

$\mathrm{I}_{\mathrm{b}}$ - income of corporations from basic activities, rubles;

$\mathrm{E}_{\mathrm{b}}$ - expenses of corporations from basic activities, rubles; 
$\mathrm{I}_{\mathrm{S}}$ - income of corporations from supporting activities, rubles;

$\mathrm{E}_{\mathrm{s}}-$ expenses of corporations from supporting activities, rubles;

$\mathrm{E}_{\mathrm{bp}}$ - expenses of corporations for conducting business processes by them, rubles;

$\mathrm{E}_{\mathrm{mi}}-$ expenses of corporations for adaptation to the microenvironment of their activities, rubles;

$\mathrm{E}_{\mathrm{ma}}$ - expenses of corporations for adaptation to the conditions of the macroenvironment of their activities, rubles;

$$
E F_{c f(p) a}=\frac{\left(I_{b}-E_{b}\right)+\left(I_{S}-E_{S}\right)}{E_{b p}}
$$

where $E F_{c f(p) a}$ - is the efficiency of corporate finance in terms of the costs of conducting business processes;

$\mathrm{I}_{\mathrm{b}}$ - income of corporations from basic activities, rubles;

$\mathrm{E}_{\mathrm{b}}$ - expenses of corporations from basic activities, rubles;

$\mathrm{I}_{\mathrm{S}}$ - income of corporations from supporting activities, rubles;

$E_{\mathrm{S}}$ - expenses of corporations from supporting activities, rubles;

$E_{b p}$ - expenses of corporations for conducting business processes by them, rubles;

$$
E F_{c f(p) b}=\frac{\left(I_{b}-E_{b}\right)+\left(I_{S}-E_{S}\right)}{E_{m i}}
$$

where $E F_{c f(p) b}$ is the efficiency of corporate finance in terms of the costs of adaptation to the conditions of the microenvironment of activity;

$\mathrm{I}_{\mathrm{b}}$ - income of corporations from basic activities, rubles;

$\mathrm{E}_{\mathrm{b}}$ - expenses of corporations from basic activities, rubles;

$\mathrm{I}_{\mathrm{S}}$ - income of corporations from supporting activities, rubles;

$\mathrm{E}_{\mathrm{s}}$ - expenses of corporations from supporting activities, rubles;

$\mathrm{E}_{\mathrm{mi}}$ - expenses of corporations for adaptation to the microenvironment of their activities, rubles;

$$
E F_{c f(p) c}=\frac{\left(I_{b}-E_{b}\right)+\left(I_{s}-E_{S}\right)}{E_{m a}}
$$

Where $E F_{c f(p) c}$ is the direct efficiency of corporate finance in terms of expenditures on adaptation to the conditions of the macro-environment of activity;

$\mathrm{I}_{\mathrm{b}}$ - income of corporations from basic activity, rubles;

$\mathrm{E}_{\mathrm{b}}$ - expenditures of corporations from basic activities, rubles;

$\mathrm{I}_{\mathrm{s}}$ - income of corporations from supporting activities, rub;

$\mathrm{E}_{\mathrm{s}}$-expenses of corporations from supporting activities, rubles;

$\mathrm{E}_{\mathrm{ma}}$-expenses of corporations to adapt to the macro environment of their activities, rubles;

$$
\mathrm{EF}_{\mathrm{cf}(\mathrm{c})}=\frac{\mathrm{E}_{\mathrm{b}} \mathrm{p}+\mathrm{E}_{\mathrm{mi}}+\mathrm{E}_{\mathrm{ma}}}{\left(\mathrm{I}_{\mathrm{b}}-\mathrm{E}_{\mathrm{b}}\right)+\left(\mathrm{I}_{\mathrm{s}}-\mathrm{E}_{\mathrm{s}}\right)},
$$

where $\mathrm{EF}_{\mathrm{cf}(\mathrm{c})}$ is the aggregate indirect efficiency of corporate finance;

$E_{b} p$ - expenses of corporations for conducting business processes by them, rubles;

$\mathrm{E}_{\mathrm{mi}}$ - expenses of corporations for adaptation to the microenvironment of their activities, rubles;

$E_{m a}$ - expenses of corporations for adaptation to the conditions of the macroenvironment of their activities, rubles;

$\mathrm{I}_{\mathrm{b}}$ - income of corporations from basic activities, rubles;

$\mathrm{E}_{\mathrm{b}}$ - expenses of corporations from basic activities, rubles;

$\mathrm{I}_{\mathrm{S}}$ - income of corporations from supporting activities, rubles;

$\mathrm{E}_{\mathrm{s}}$ - expenses of corporations from supporting activities, rubles; 


$$
\mathrm{EF}_{\mathrm{cf}(\mathrm{c}) \mathrm{a}}=\frac{\mathrm{E}_{\mathrm{bp}}}{\left(\mathrm{I}_{\mathrm{b}}-\mathrm{E}_{\mathrm{b}}\right)+\left(\mathrm{I}_{\mathrm{s}}-\mathrm{E}_{\mathrm{s}}\right)}
$$

where $\mathrm{EF}_{\mathrm{cf}(\mathrm{c}) \mathrm{a}}$ is the indirect efficiency of corporate finance in terms of the costs of conducting business processes;

$\mathrm{E}_{\mathrm{b}} \mathrm{p}$ - expenses of corporations for conducting business processes by them, rubles;

$\mathrm{I}_{\mathrm{b}}$ - income of corporations from basic activities, rubles;

$\mathrm{E}_{\mathrm{b}}$ - expenses of corporations from basic activities, rubles;

$\mathrm{I}_{\mathrm{S}}$ - income of corporations from supporting activities, rubles;

$E_{S}$ - expenses of corporations from supporting activities, rubles;

$$
\mathrm{EF}_{\mathrm{cf}(\mathrm{c}) \mathrm{b}}=\frac{E_{m i}}{\left(\mathrm{I}_{\mathrm{b}}-\mathrm{E}_{\mathrm{b}}\right)+\left(\mathrm{I}_{\mathrm{s}}-\mathrm{E}_{\mathrm{s}}\right)},
$$

where $\mathrm{EF}_{\mathrm{cf}(\mathrm{c}) \mathrm{b}} \mathrm{b}$ is the indirect efficiency of corporate finance in terms of the costs of adaptation to the conditions of the microenvironment of activity;

$E_{m i}$ - expenses of corporations for adaptation to the microenvironment of their activities, rubles;

$\mathrm{I}_{\mathrm{b}}$ - income of corporations from basic activities, rubles;

$\mathrm{E}_{\mathrm{b}}$ - expenses of corporations from basic activities, rubles;

$\mathrm{I}_{\mathrm{S}}$ - income of corporations from supporting activities, rubles;

$\mathrm{E}_{\mathrm{S}}$ - expenses of corporations from supporting activities, rubles;

$$
\mathrm{EF}_{\mathrm{cf}(\mathrm{c}) \mathrm{c}}=\frac{E_{m a}}{\left(\mathrm{I}_{\mathrm{b}}-\mathrm{E}_{\mathrm{b}}\right)+\left(\mathrm{I}_{\mathrm{s}}-\mathrm{E}_{\mathrm{s}}\right)},
$$

where $\mathrm{EF}_{\mathrm{cf}(\mathrm{c}) \mathrm{c}}$ is the indirect efficiency of corporate finance in terms of the costs of adaptation to the conditions of the macroenvironment of activity;

$E_{m a}$ - expenses of corporations for adaptation to the conditions of the macroenvironment of their activities, rubles;

$\mathrm{I}_{\mathrm{b}}$ - income of corporations from basic activities, rubles;

$\mathrm{E}_{\mathrm{b}}$ - expenses of corporations from basic activities, rubles;

$\mathrm{I}_{\mathrm{S}}$ - income of corporations from supporting activities, rubles;

$E_{S}$ - expenses of corporations from supporting activities, rubles.

\begin{tabular}{|c|c|c|c|c|}
\hline \multirow[b]{2}{*}{ № } & \multicolumn{2}{|c|}{ Effectiveness parameter } & \multicolumn{2}{|c|}{ Sign of effectiveness } \\
\hline & Direct indicators & Contents & $\begin{array}{l}\text { Indirect } \\
\text { indicators }\end{array}$ & Contents \\
\hline \multicolumn{5}{|c|}{ General performance indicators of corporate finance } \\
\hline 1 & $\begin{array}{l}\text { Aggregate direct } \\
\text { efficiency of } \\
\text { corporate finance }\end{array}$ & $\begin{array}{l}\text { Profit of corporations } \\
\text { per unit of total costs, } \\
\text { including the cost of } \\
\text { their business processes, } \\
\text { the cost of adapting to } \\
\text { the micro and macro } \\
\text { environment of their } \\
\text { activities }\end{array}$ & $\begin{array}{l}\text { Cumulative } \\
\text { indirect } \\
\text { efficiency of } \\
\text { corporate } \\
\text { finance }\end{array}$ & $\begin{array}{l}\text { Aggregate costs of } \\
\text { corporations, } \\
\text { including the cost of } \\
\text { their business } \\
\text { processes, the cost of } \\
\text { adapting to the micro } \\
\text { and macro } \\
\text { environment of their } \\
\text { activities, per unit of } \\
\text { profit }\end{array}$ \\
\hline \multicolumn{5}{|c|}{ Particular indicators of the effectiveness of corporate finance } \\
\hline 2 & $\begin{array}{l}\text { Direct efficiency of } \\
\text { corporate finances by } \\
\text { expenditures on } \\
\text { business processes }\end{array}$ & $\begin{array}{l}\text { Profit of corporations } \\
\text { per unit of costs of their } \\
\text { business processes }\end{array}$ & $\begin{array}{l}\text { Indirect } \\
\text { efficiency of } \\
\text { corporate } \\
\text { finances by }\end{array}$ & $\begin{array}{l}\text { Costs of corporations } \\
\text { to conduct their } \\
\text { business processes per } \\
\text { unit of profit }\end{array}$ \\
\hline
\end{tabular}

The interpretation of corporate finance performance indicators is presented in Table 1.

Table 1. Performance indicators of corporate finance. 


\begin{tabular}{|c|c|c|c|c|}
\hline & & & $\begin{array}{l}\text { expenditures } \\
\text { on business } \\
\text { processes }\end{array}$ & \\
\hline 3 & $\begin{array}{l}\text { Direct efficiency of } \\
\text { corporate finance on } \\
\text { the cost of adapting } \\
\text { to the conditions of } \\
\text { the micro- } \\
\text { environment of } \\
\text { activity }\end{array}$ & $\begin{array}{l}\text { Profit of corporations } \\
\text { per unit of costs for } \\
\text { adapting to the micro } \\
\text { environment of their } \\
\text { operations }\end{array}$ & $\begin{array}{l}\text { Indirect } \\
\text { efficiency of } \\
\text { corporate } \\
\text { finance on } \\
\text { the cost of } \\
\text { adapting to } \\
\text { the } \\
\text { conditions of } \\
\text { the micro- } \\
\text { environment } \\
\text { of activity }\end{array}$ & $\begin{array}{l}\text { Costs of corporations } \\
\text { to adapt to the micro } \\
\text { environment of their } \\
\text { activities per unit of } \\
\text { profit }\end{array}$ \\
\hline 4 & $\begin{array}{l}\text { Direct efficiency of } \\
\text { corporate finance in } \\
\text { terms of } \\
\text { expenditures on } \\
\text { adaptation to the } \\
\text { macro environment } \\
\text { of activity }\end{array}$ & $\begin{array}{l}\text { Profit of corporations } \\
\text { per unit of costs for } \\
\text { adapting to the macro } \\
\text { environment of their } \\
\text { activities }\end{array}$ & $\begin{array}{l}\text { Indirect } \\
\text { efficiency of } \\
\text { corporate } \\
\text { finance in } \\
\text { terms of } \\
\text { expenditures } \\
\text { on adaptation } \\
\text { to the } \\
\text { conditions of } \\
\text { the macro } \\
\text { business } \\
\text { environment }\end{array}$ & $\begin{array}{l}\text { Costs of corporations } \\
\text { to adapt to the macro } \\
\text { environment of their } \\
\text { activities per unit of } \\
\text { profit }\end{array}$ \\
\hline
\end{tabular}

Based on the content of indicators in table 1, let us form the aggregate (general) indicators of corporate finance efficiency through multiples-additive dependence with private indicators entering into the unified system with them. Operating with them and the property of inverse proportionality (multiplicity) of effectiveness and costs, we form the general indicators of corporate finance efficiency from private indicators (formulas (9), (10)):

$$
E F_{c f(p)}=\frac{1}{E F_{c f(p) a}+E F_{c f(c) b}+E F_{c f(c) c}},
$$

where $E F_{c f(p)}$ is the aggregate direct efficiency of corporate finance;

$E F_{c f(p) a}$ - the indirect efficiency of corporate finance in terms of the costs of conducting business processes;

$E F_{c f(c) b}$ is the indirect efficiency of corporate finance in terms of the costs of adaptation to the conditions of the microenvironment of activity;

$E F_{c f(c) c}$ is the indirect efficiency of corporate finance in terms of the costs of adaptation to the conditions of the macroenvironment of activity;

$$
E F_{c f(c)}=\frac{1}{E F_{c f(p) a}}+\frac{1}{E F_{c f(c) b}}+\frac{1}{E F_{c f(c) c}},
$$

where $E F_{c f(c)}$ is the aggregate indirect efficiency of corporate finance;

$E F_{c f(p) a}$ - direct efficiency of corporate finances on the costs of conducting economic processes;

$E F_{c f(c) b}$ - direct efficiency of corporate finances on the costs of adaptation to the conditions of the micro-environment of activity;

$E F_{c f(c) c}$ - direct efficiency of corporate finances on the costs of adaptation to the conditions of the macro environment of activity. 
The proposed accounting and management toolkit is characterized by complexity and consistency of factor indicators, whose degree of influence on the resulting indicators formed by them is real to determine at the expense of their multiple-additive interaction between themselves in the developed system and apply in making managerial decisions on the balance of the resulting regression coefficients, which will be analyzed by the effectiveness of corporate finance.

\section{Discussion}

Financial control, being a type of management activity, is a system associated with the observation and verification of the financial activities of corporations to assess the effectiveness of the decisions, identifying deviations and taking measures to eliminate and prevent them in the future.

Financial control is designed to ensure the growth of efficiency of production activities; compliance with current legislation in the sphere of taxation; correctness of formation and execution of the budget; correctness of bookkeeping; verification of the efficient use of resources.

The financial control system includes the accounting system, the control environment, and control tools.

The accounting system consists of the company's accounting policy; the structural subdivision responsible for accounting and reporting; the document flow procedure, the procedure for reflecting business operations; forms and methods of data summarization in registers; means of accounting automation and reporting preparation.

Control environment is the interrelated functions and organizational measures taken by the corporation's management to organize and operate the internal control system by means of verifying the employees' performance of their duties. The control environment consists of the following elements: basic principles of management of an economic subject; organizational and production structure; distribution of powers and responsibilities; personnel policy; the order of formation of financial reporting for external users; the order of organization of the management accounting and formation of internal reporting; the order of functioning of internal control service.

The control tools that ensure the actual implementation of financial control include:

- a regulatory framework including a set of normative documents formed and adopted in a company which define the activity of the company and its structural subdivisions;

- control procedures, which are a set of methods and methods developed by the company's management in order to achieve the set goals and aimed at functioning and interaction;

- verification of the quality of the internal control system carried out by continuous monitoring of its functioning in order to detect errors in its work, determine the degree of its compliance with the goals and objectives of the corporation, justify proposals and monitor the implementation of decisions made for its further development.

The organization of the internal financial control system is a complex process that includes the following stages:

1. Critically analyzes and compares the goals of the corporation defined for the previously established tactics, strategy, areas of work, economic conditions with the size, organizational structure, types of activity, and potential opportunities.

2. A new concept of company development is developed and documented, which meets the conditions of the market, a complex of measures, which allows to develop the business concept and contribute to successful realization of its goals, strengthening of its market position. Development of these documents, which include provisions on financial investment, production and technological, supply and sales, personnel and accounting 
policies, should be carried out, based on an in-depth analysis of each of the elements of the policy and the choice of the most acceptable of the available options for the company;

3. The efficiency is analyzed and the functioning management structure is corrected. The provision on the Organizational structure, which contains a description of the organizational links with the adjustment of administrative, methodological, functional subordination, the direction of activities, the formed order of relations, is clarified;

4. Standard formal procedures of control of individual economic and financial operations are developed that will facilitate the ordering of relations between employees in the process of financial control, effective resource management, assessment of the reliability of information for management decision-making;

5. The internal control service is being organized and the ways of developing the internal financial control system are being determined taking into account the constantly changing conditions of the corporation's functioning;

6. Forecast assessment of the efficiency of the financial internal control system is carried out.

Thus, the system of internal financial control should be aimed at a real estimation of the current financial condition of corporations. It should carry out a complex analysis of all sides of corporations' functioning, pay special attention to problems of their development and identify the most risk-prone objects, determine the sources and causes of negative results in the activity of corporations.

\section{Conclusions}

The toolkit formed and proposed in the article, which includes a system of indicators of corporate finance efficiency, has several advantages:

1. Provides a complete list of conditions of the activities carried out;

2. Covers all items of costs related to controlled and uncontrolled environment, compared with the results obtained;

3. Gives an opportunity to rank the share of cost indicators on the total result and the share of performance indicators on the total cost of commercial efforts.

Applying this system of indicators, corporations will be able to maximize the marginal result (marginal profit) and minimize the marginal costs (marginal expenses) and thus optimize their financial relations.

Besides, on the basis of such approach it is possible to conduct the complex and systematic accounting of factor indicators. The proposed system is distinguished by the integrity and organic nature of the resulting and factor indicators of the efficiency of corporate finance, since it is associated with the traditional interpretation of its essence and reveals the element-by-element relationship between the efficiency and cost of monetary resources. It will help the accounting-management personnel to define the directions of improvement of general at simultaneous improvement of particular indicators of efficiency of corporate finances.

Also it is necessary to note that in modern economic conditions activity of corporations is a subject of attention of a wide range of participants of market relations which are interested in results of their functioning. To ensure the effective functioning of corporations, management personnel, first and foremost, need to assess the real financial capabilities of both their enterprise and existing potential competitors. In this regard, internal financial control becomes the most important link in the activities of the enterprise, determining the competitiveness and potential in business cooperation. 


\section{References}

1. F. Jiang, Zh. Jiang, K.A. Kim, Journal of Corporate Finance 63, 101309 (2020) https://doi.org/10.1016/j.jcorpfin.2017.12.001

2. M.R. Moritzen, A. Schandlbauer, Journal of Corporate Finance 65, 101502 (2020) https://doi.org/10.1016/j.jcorpfin.2019.101502

3. A. Zakirova, G. Klychova, G., Ostaev et al, E3S Web of Conferences 164, 10009 (2020) https://doi.org/10.1051/e3sconf /202016410009

4. D. Cumming, V. Verdoliva, F. Zhan, Emerging Markets Review 31, 100792 (2020) https://doi.org/10.1016/j.ememar.2020.100792

5. M. Zhou, K. Li, Zh. Chen, International Review of Financial Analysis 73, 101652 (2021) https://doi.org/10.1016/j.irfa.2020.101652

$\begin{array}{llllll}\text { 6. J. Ang, Global Finance Journal 22, } 100483 & \text { (2019) }\end{array}$ https://doi.org/10.1016/j.gfj.2019.100483

7. F. Abraham, J.J. Cortina, S.L. Schmukler, Journal of Banking \& Finance 122, 105987 (2021) https://doi.org/10.1016/j.jbankfin.2020.105987

8. Y.G. Muradoğlu, C. Onay, K. Phylaktis, International Review of Financial Analysis 33, 138-157 (2014) https://doi.org/10.1016/j.irfa.2014.02.002

9. R. Kabir, Journal of Banking \& Finance 36, 2865-2867 (2012) https://doi.org/10.1016/j.jbankfin.2012.04.023

10. M. Arslan, A. Alqatan, Heliyon 6, e03520 (2020) https://doi.org/10.1016/j.heliyon.2020.e03520

11. M.R. Silva, Journal of Economic Dynamics and Control 102, 1-28 (2019) https://doi.org/10.1016/j.jedc.2019.03.001

12. S.K. Nguyen, X.V. Vo, T.M.T. Vo, Heliyon 6, e03788 (2020) https://doi.org/10.1016/j.heliyon.2020.e03788

13. L. Noring, Cities 88, 125-135 (2019) https://doi.org/10.1016/j.cities.2019.01.002

14. G. Klychova, A. Zakirova, S. Alibekov, et al, Advances in Intelligent Systems and Computing 1258 AISC, 669-686 (2021) https://doi.org/10.1007/978-3-030-574505_58

15. A. Zakirova, G. Klychova, K. Mukhamedzyanov et al, Advances in Intelligent Systems and Computing 1258 AISC, 687-707 (2021) https://doi.org/10.1007/978-3-030-574505_59

16. Ch. Dang, Zh. Li, Ch. Yang, Journal of Banking \& Finance 86, 159-176 (2018) https://doi.org/10.1016/j.jbankfin.2017.09.006

17. C. Clark, J.A. Brown, J Bus Ethics 132, 565-577 (2015) https://doi.org/10.1007/s10551-014-2358-6

18. K. Daxhammer, M. Luckerta, M. Doerr, T. Bauernhansla, Procedia Manufacturing 39, 1354-1362 (2019) https://doi.org/10.1016/j.promfg.2020.01.322

19. A. Klychova, G. Klychova, A. Zakirova et al, E3S Web of Conferences 110, 02072 (2019) https://doi.org/10.1051/e3sconf/201911002072

20. C. Gurău, L.-P. Dana, Technological Forecasting and Social Change 153, 119935 (2020) https://doi.org/10.1016/j.techfore.2020.119935

21. J.-M. Sahut, L.-P. Dana, F. Teulon, Technological Forecasting and Social Change 163, 120425 (2021) https://doi.org/10.1016/j.techfore.2020.120425 
22. Zh. Shuangling, C. Guohua, W. Lijuan, The North American Journal of Economics and Finance 50, 100991 (2019) https://doi.org/10.1016/j.najef.2019.100991

23. G. Klychova, A. Zakirova, R. Mannapova et al, E3S Web of Conferences 110, 02075 (2019) https://doi.org/10.1051/e3sconf/201911002075

24. G. Klychova, A. Zakirova, R. Nurieva, et al, Advances in Intelligent Systems and Computing 1258 AISC, 738-758 (2021)

25. E. Agliardi, R. Agliardi, W. Spanjers, Journal of Business Research 69, 6012-6020 (2016) https://doi.org/10.1016/j.jbusres.2016.05.016

26. A. Geddes, T.S. Schmidt, Research Policy 49, 103985 (2020) https://doi.org/10.1016/j.respol.2020.103985

27. J.E. Edmonds, R.D. Leece, Research in Accounting Regulation 29, 44-51 (2017) https://doi.org/10.1016/j.racreg.2017.04.005

28. I. Goldstein, D. Hackbarth, Journal of Corporate Finance 29, 535-541 (2014) https://doi.org/10.1016/j.jcorpfin.2014.10.018

29. Dz. Faizrakhmanov, A. Zakirova, G. Klychova et al, E3S Web of Conferences 91, 06004 (2019) https://doi.org/10.1051/e3sconf/20199106004

30. A. Habib, M.M. Hasan, International Review of Financial Analysis 61, 188-201 (2019) https://doi.org/10.1016/j.irfa.2018.12.004

31. H. Farag, S. Johan, Journal of Corporate Finance 4, 101879 (2021) https://doi.org/10.1016/j.jcorpfin.2020.101879

32. S. Clausen, Ch.R. Flor, Journal of Banking \& Finance 61, 64-80 (2015) https://doi.org/10.1016/j.jbankfin.2015.08.020

33. P. Wetzel, E. Hofmann, International Journal of Production Economics 216, 364-383 (2019) https://doi.org/10.1016/j.ijpe.2019.07.001

34. G. Klychova, A. Zakirova, E. Sadrieva et al, E3S Web of Conferences 91, 06002 (2019) https://doi.org/10.1051/e3sconf/20199106002

35. M. Renzetti, Corporate Finance: Financial Control. International Encyclopedia of the Social \& Behavioral Sciences (2015) https://doi.org/10.1016/B978-0-08-0970868.73030-3 